\title{
Human factors engineering in oil and gas - a review of industry guidance
}

\author{
Martin Robb ${ }^{\mathrm{a},{ }^{*}}$ and Gerald Miller ${ }^{\mathrm{b}}$ \\ ${ }^{a}$ Human Factors Team, Atkins, 920 Memorial City Way, Suite 700, Houston, TX, 77024 USA \\ ${ }^{b}$ Independent Maritime Professional, Ge Miller \& Associates, 37303 S. Vista Park Drive \\ Tucson, AZ, 85739 USA
}

\begin{abstract}
Oil and Gas Exploration and Production activities are carried out in hazardous environments in many parts of the world. Recent events in the Gulf of Mexico highlight those risks and underline the importance of considering human factors during facility design. Ergonomic factors such as machinery design, facility and accommodation layout and the organization of work activities have been systematically considered over the past twenty years on a limited number of offshore facility design projects to a) minimize the occupational risks to personnel, b) support operations and maintenance tasks and c) improve personnel wellbeing. During this period, several regulators and industry bodies such as the American Bureau of Shipping (ABS), the American Society of Testing and Materials (ASTM), the UK's Health and Safety Executive (HSE), Oil and Gas Producers (OGP), and Norway's Petroleum Safety Authority (PSA) have developed specific HFE design standards and guidance documents for the application of Human Factors Engineering (HFE) to the design and operation of Oil and Gas projects. However, despite the existence of these guidance and recommended design practise documents, and documented proof of their value in enhancing crew safety and efficiency, HFE is still not well understood across the industry and application across projects is inconsistent. This paper summarizes the key Oil and Gas industry bodies' HFE guidance documents, identifies recurring themes and current trends in the use of these standards, provides examples of where and how these HFE standards have been used on past major offshore facility design projects, and suggests criteria for selecting the appropriate HFE strategy and tasks for future major oil and gas projects. It also provides a short history of the application of HFE to the offshore industry, beginning with the use of ASTM F 1166 to a major operator's Deepwater Gulf of Mexico facility in 1990 and the application of HFE to diverse world regions. This latter point highlights the need to consider user populations when selecting HFE design criteria, an aspect strongly emphasized in current industry guidance.
\end{abstract}

Keywords: oil and gas, facilities design, regulations, energy

\section{Introduction}

Brazil is the ninth largest energy consumer in the world and the third largest in the Western Hemisphere (after the United States and Canada), and has been a net exporter of oil and gas since 2009 [1]. Brazil's proven oil reserves are considerable, and may be comparable with those of the UK North Sea [2]. Petrobras, Brazil's largest energy company, re- cently announced plans to expand their rig fleet and triple production to 6 million barrels a day by 2020 [3] -a rate that would equal the North Sea's peak production (achieved in 1999, [4]). Meeting these production targets will require accessing hydrocarbons from fields located at substantial depths; for example, the giant Tupi field which lies some 4.5 miles beneath the ocean's surface in the subsalt layer.

Corresponding author. E-mail: martin.robb@atkinsglobal.com / +1 7134014729. 


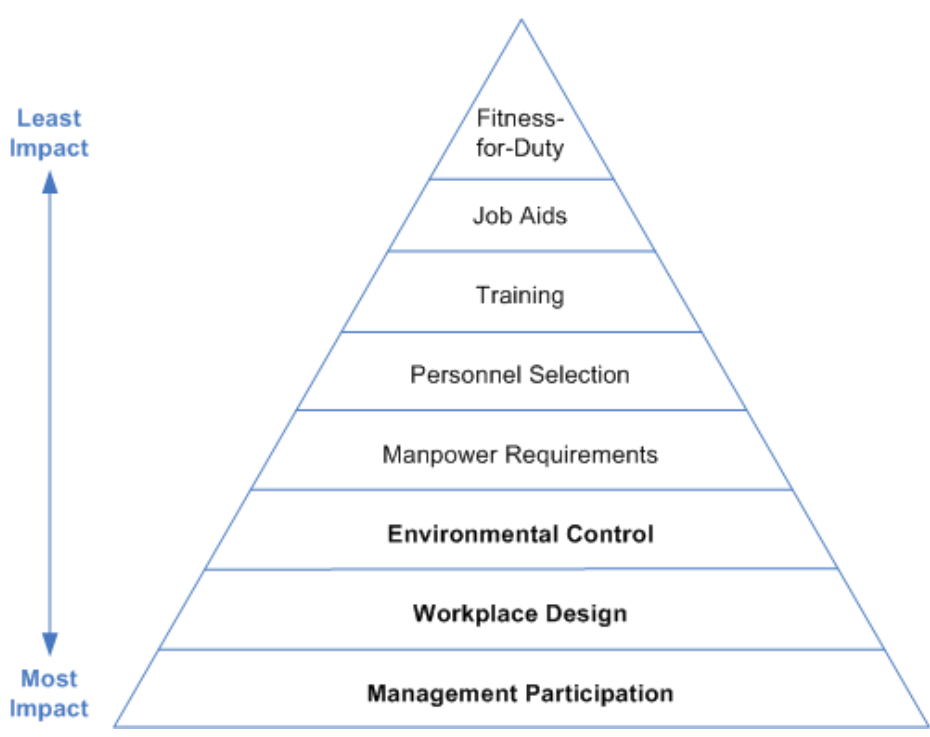

Figure 1

The Human and Organizational Factors "Triangle of Effectiveness" model for reduction of human errors. HFE addresses Workplace Design and Environmental Control, two areas with a high impact that are founded on Management Participation.

Finding and producing offshore oil and gas contains inherent risks that are especially distinct in deep waters. The explosions and subsequent sinking of Petrobras' P-36 with the death of 11 workers in March 2001 is a reminder of those risks, as is the April 2010 sinking of the Deepwater Horizon semisubmersible (which also claimed 11 workers' lives and led to total loss of the facility). Human Factors deficiencies such as poorly implemented alarm systems and human-system interfaces that did not support effective situational awareness permitted escalation of these events. A lack of risk awareness, issues with emergency response training, and insufficient safety culture (manifesting as a focus on financial performance and avoidance of necessary maintenance activities) were also clearly implicated in both incidents.

Human Factors Engineering (HFE) is a discipline that aims to systematically address human-system integration issues via practical activities applied during the design, fabrication, construction and decommissioning of oil and gas facilities. The aim is to reduce the opportunities for human error and minimize the effects of the errors that do occur by designing equipment and work systems in accordance with sound HFE principles. The effect of HFE activities should be an installation that supports situational awareness of those working in control rooms, build- ings and other areas of the plant, facilitates maintenance activities and supports emergency responses.

HFE applies to the areas of workplace design and environmental control; two application areas with a high impact on safety and operator performance according to the Human and Organizational Factors' "Triangle of Effectiveness" model (

), which is explained further in other papers (e.g. [5], [6]). As has been noted [7] HFE is a new discipline to oil and gas, and as such is only able to be applied effectively on the basis of adequate Management Participation and buy-in.

Systematic HFE programmes have been implemented within Major Capital Projects in the offshore sector over a period of at least twenty years. Much has been learned during this period and this experience is included within industry-specific guidance. Respected industry bodies provide this guidance, and several regulators also provide standards recommending or requiring HFE activities. Professional personnel are available to those companies who wish to apply HFE to the design of their facilities.

It is noted that application of HFE has historically been inconsistent on projects. One of the reasons given for this is that guidance on specific application has been lacking [8]; for example the American Petroleum Institute (API's) recently mandated Recommended Practice 75 [9] contains instructions that 
Human Factors should be considered, but no specific guidance on how this should be achieved is given.

Industry-specific HFE guidance that may bridge this gap is becoming available; it is harmonious, practical and based on project experience. The remainder of this paper aims to summarize some of the available guidance, and introduce the reader to the main principles of application.

\section{Industry Guidance}

\subsection{Regulators' guidance}

National Regulators have a large part to play by providing a driver for HFE, encouraging compliance and following-up. Several regulators provide structured guidance relating to HFE and have expectations that facilities designed for use in their area of jurisdiction will provide documented evidence of a systematic approach to HFE.

\subsubsection{HSE -UK}

Since 1992 the UK has required that all fixed and mobile offshore installations operating in its waters shall have a safety case accepted by the Health and Safety Executive (HSE; [10]). The safety case regime focuses on prevention of major accidents, and the HSE recognizes that the greatest opportunity to eliminate or minimize hazards is during design. The HSE also recognizes that decommissioning of facilities may require HFE input. Assessment Principles for Offshore Safety Cases (APOSC, [11]) contains the provision that "the major accident risk evaluation should take account of human factors" (Principle 8) and "...the (safety) case should show how relevant good practice and judgement based on sound engineering, management and human factors principles have been taken into account" (Principle 13). Several sentences provide more specific guidelines, including:

..."consider people as both a key element in safe operation and as a potential cause of major accidents and their escalation" (Paragraph 43);

"Safety critical tasks should be analysed to demonstrate that task performance could be delivered to the specified performance when required..." (Paragraph 45); and

"The effects of hazards on human performance should be evaluated to ensure decision-making capability or the ability to evacuate or escape does not become impaired" (Paragraph 48).
The paragraphs above indicate the kinds of HFE studies and analysis expected and it is clear that $\mathrm{Hu}-$ man Factors expectations are high within the UK regulator.

One of the key drivers towards this maturity was the 1988 Piper Alpha disaster and subsequent investigation that identified many Human Factors failings and led to the HSE taking responsibility for offshore safety.

Specific design guidance is provided by the HSE in the form of web-based resources and several downloads (e.g. Human Factors and Ergonomics [12]; Human Factors: Design [13]). Specific guidance on implementing Human Factors into oil and gas projects is not provided; however a 2002 research report discussed the application of military-based Human Factors Integration (HFI) to the oil and gas sector [14].

\subsubsection{NOPSA-Australia}

In common with the UK HSE, Australia's National Offshore Petroleum Safety Authority (NOPSA) runs a performance-based regime with an emphasis on safety cases. NOPSA commenced operations in 2005 and a recent presentation made by the CEO of NOPSA [15] indicates the organization's awareness and focus on Human Factors issues. NOPSA is currently aiming to develop specific human factors guidance in the near future [16].

\subsubsection{Petroleum safety authority -Norway}

The Norwegian authorities provide technical guidance on HFE that is generally prescriptive rather than goal-setting and requires systematic HF input for new facilities and modifications. NORSOK S-005 (Working Environment Analyses and Documentation, [17]) describes HFE roles and responsibilities, activities that should be carried out and how they should be documented. NORSOK S-002 (Working Environment, [18]) is a technical reference that contains design criteria, describes activities and prescribes methods. The NORSOK standards were intended to replace company specifications and function as references under the regulations; criteria they seem to meet well (some offshore companies publish their own additions to the requirements).

The prescriptive nature of the Norwegian system makes requirements and expectations generally clear, and the NORSOK system has many principles and design criteria in common with the other current good practice HFE documents. The Petroleum Safe- 
ty Authority (PSA) is well resourced and follows up major projects via detailed audits.

\subsubsection{ANP-Brazil}

Brazil's Normative Regulations (NRs) for HSE relate to HFE; for example NR 12 (which includes provisions for machinery and equipment safety) NR 17 (workstation ergonomics, manual work and material handling arrangements) and NR 26 (Safety Signs).

The National Agency of Petroleum, Natural Gas and Biofuels (ANP) issued a resolution in 2007 requiring a full safety management system for projects ("Technical Regulation of Operational Safety Management System for Maritime Drilling Installations and Oil and Natural Gas Production"; Resolution ANP $\mathrm{N}^{\circ} 43$ ). This resulted in a goal-setting model with 17 management practices organized into three areas (Management, Leadership and Personnel; Facilities and Technology and Operational Practices). The first area includes reference to Work Environment and Human Factors [19], and includes the provision that "codes \& standards for Work Environment and Human Factors should be identified and considered in design, construction, installation and decommissioning, establishing a potentially broad scope for HFE on projects.

An extensive HFE programme was carried out during FEED, Detailed Design and Construction of the Frade FPSO by one of the authors' colleagues, and the Brazilian-made P-56 semi-submersible reportedly has a swimming pool and large outdoor football field [20], indicating considerable investment in worker wellbeing.

\subsubsection{Engineering organizations' guidance}

Early HFE guidance relevant to major projects was provided to the offshore industry by engineering organizations such as the International Maritime Organization (IMO), the Institute of Mechanical Engineers (IMechE) and the Institute of Electrical and Electronics Engineers (IEEE). The latter group has been involved with the development of Human Factors and Ergonomics from its early days, having sponsored early HF symposia (e.g. Fatigue Symposium, 1953, and Human Factors in Equipment Design, 1954). IMechE continues to develop documents for HF applications covering several industries. The IEEE standards (e.g. [21] and [22]) are aimed at addressing Human Factors within nuclear power generation.

IMO has produced guidance notes relevant to the offshore / marine sector, such as IMO Circular 834
(Guidelines for Engine-Room Layout, Design and Arrangement, [23]). This short document identifies the engine room as the most hazardous area on a ship, and provides guidance covering familiarity, occupational health, ergonomics, minimization of risk through layout \& design, and survivability. IMO Circular (982: Guidelines on Ergonomic Criteria for Bridge Equipment and Layout, [24]) contains general requirements for bridge layout and workstation design to include consideration of the activities required at each station and encompasses arrangement of controls \& displays, alarms, information display types, colour coding, fonts and wording of procedures. These notes are a worthwhile reminder for the designer to consider HFE principles, but given their unspecific nature they cannot be used as standalone design requirements. It should be noted that HFE professionals are not the authors of such guidance notes and they may in fact contradict currently accepted HFE design standards [5].

ASTM International is a developer of voluntary consensus standards and has developed two key offshore-specific HFE guidance documents. ASTM-F1337 (Standard Practice for Human Engineering Program Requirements for Ships and Marine Systems, Equipment, and Facilities [25]) was developed by the US Navy and principally reflects the US Government's HFE requirements for ship procurement contracts. The document's content addresses scaling and integrating a Human-System Integration (HSI) program (which is mandated for US Government acquisitions) and details the expected deliverables.

The document provides HSI objectives for each project phase and outlines factors necessary for effective HSI delivery. It also provides personnel qualification and experience requirements for those who will carry out HFE activities.

The activities recommended in ASTM-F-1337 are broad and comprehensive, covering seven HSI domains (Manpower, Personnel, Training, Human Factors Engineering, Environment, Safety and Occupational Health, Personnel Survivability and Habitability) and therefore go beyond HFE to encompass each of the other HOF disciplines. Although intended to be applicable to both ships and offshore structures, the ASTM document is focused on military procurement and uses specific navy terms and includes U.S. Navy specific requirements throughout the document. These are likely to be unfamiliar to readers from commercial shipping and offshore industries. The activities described in ASTM-F-1337 are also based on a cyclical / iterative design method that also may 
not be fully transferable to the normally shorter timescales of an upstream oil and gas project.

A second ASTM document (ASTM-F-1166, [26]), provides specific design criteria for maritime vessels and structures, focusing on Human-Machine Interfaces (HMI) such as those between operators and control panels, workstations, alarms and displays, machinery spaces and equipment items. Now in its third version, the original version of this document was prepared in 1988 and was influenced by the widely used and authoritative Military Standard 1472F [27], among other references.

The document opens with key HFE principles (e.g. consider system users during design, identify and attenuate possibilities for human error; ensure similar items are installed consistently; ensure spatially match relationships between controls, displays and the associated items, and consider the backgrounds and cultures of users). However, the bulk of the fifteen chapter document contains specific design recommendations detailing aspects such as choice, location and arrangement of controls and displays and their integration (including audible displays and alarms), workstation / workplace design with specific details on access means (ladders, stairs, ramps, doors and hatches etc.) and typical equipment items. There are also sections on living and working environments, labeling and instruction design, hazards, HumanComputer Interfaces, communications and material handling.

ASTM-F-1166 contains many figures and tables, is highly practical and provides clear design criteria based on research and practice. The current version was updated in 2007 to include design criteria modified for other world populations in recognition of the fact that many seafarers and offshore personnel are from countries other than where the facilities are designed and built [28]. A simple example is provided in Fout! Verwijzingsbron niet gevonden., which indicates that the maximum permitted valve height should be lower for certain populations.

Because of its emphasis on providing design criteria suitable for a wide range of user populations ASTM- F-1166 is now being used internationally for the design of ships and offshore facilities.

The American Bureau of Shipping (ABS) is also active in publishing HFE guidance. As an example their "Guide For Crew Habitability on Offshore Installations" [29] provides useful criteria and testing methods for environmental aspects. "Guidance Notes for The Application of Ergonomics to Marine Systems" [30] is a substantial HFE design manual. An industry-specific HFE guidance document was re- cently described within a paper outlining ABS' practical approach to HFE [31], and it is understood that "Guidance Notes on the Implementation of Human Factors Engineering into the Design of Offshore Installations" [32] has been written and shall soon be published. This document is expected to include recommendations on integrating $\mathrm{HFE}$ into project management systems consistent with the aims of the American Petroleum Institute (API)'s RP 75 [9], which incidentally is a key driver for ABS' HFE activities. ABS sets a high standard for the quality of their publications and this document would be welcomed, however it remains unpublished at the time of writing.

\subsection{Major oil and gas companies' guidance}

The design requirements described above have been applied to the design of some oil and gas facilities by the procuring organization simply stipulating that the ship or offshore structure be designed in accordance with one or more of the design standards. However, this may not be a practical approach in all cases since the documents are lengthy and much of the content may be irrelevant to some projects orequipment vendors (who may also lack the expertise to properly apply the standards).

Therefore, some offshore oil and gas companies have used the above-referenced HFE design standards to create their own in-house company-, or even project-specific HFE design requirements documents. By extracting the pertinent and relevant parts from the above discussed HFE design guides and standards the companies have created their own HFE design requirements. By making the required HFE documents smaller and more directed at a particular company's projects it makes it easier for all parties involved in the design process to understand exactly what is required from a HFE perspective on a project-by-project basis. For example, Chevron's Safety in Designs [33] is a company-specific design manual applicable to onshore and offshore projects that provides guidance on the main elements of plant design and layout such as stairs, ladders and platforms, machinery guarding, access and layout, material handling and environmental requirements.

Other major upstream oil and gas companies have also produced in-house technical standards and processes for integrating HFE into projects; for example Shell has a number of Design Engineering Practices and BP has produced guidance and Engi- 
neering Technical Practices that cover HFE and re- lated

issues.

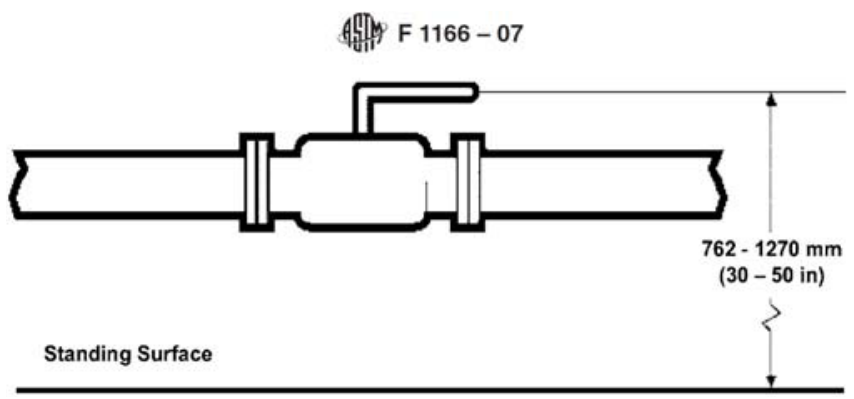

Figure 2

Image from ASTM-F-1166 indicating modification of valve height design criteria for world populations.

Figure's Caption reads, "These dimensions are appropriate for the 5 th $\%$ female to the 95 th $\%$ male maritime personnel worldwide except that the maximum height dimension should be reduced to $1143 \mathrm{~mm}(45 \mathrm{in}$.) to accommodate 5 th $\%$ females from geographic locations such as West Africa, Southeast Asia, China, parts of Latin America, India, and Japan.”

\subsection{Industry associations' guidance}

There is some commonality between these company standards and they share a practical approach to HFE. However maintenance of HFE guidance documents and technical standards requires considerable effort from specialist personnel, and not all companies have this capacity. Industry bodies therefore have a role to play in generating applicable practice, and the International Association of Oil and Gas Producers (OGP), a UK-based industry body that counts major oil companies as its members, recently released a document that outlines an "agreed" approach to HFE. The document is titled "Human Factors Engineering in Projects" and is available for free download from the OGP website [34].

The document scope deals with HFE issues within capital expenditure programmes, and is focused on HFE in design. The document places particular emphasis on ensuring HFE cost-effectiveness by planning the appropriate level of HFE competence and involvement according to the project's size and complexity. For large projects, HFE roles are identified both for engineering contractors and the sponsoring companies and formation of an HFE Working Group is recommended. Recommended activities are given over 5 main project stages:

-HFE Screening: reviewing the project for HFE risks, issues and opportunities.

-Design Analysis: verifying that specified technical standards cover HFE issues and risks, and analyzing design to ensure that safety-critical tasks are supported.
-Design Validation: following up on identified issues during detailed design project phase and verifying that HFE design quality is not compromised during construction.

-Support to start-up: ensuring HFE recommendations implemented and supporting start-up audit / commissioning inspections.

-Operational feedback: review the success of HFE and identify lessons learned.

This a structured approach that involves HFE at a suitable time in the project, includes guidance on preparing an HFE programme, continuity of HFE on the project and continuous improvement.

The guidance contains several useful appendixes which include clear visual examples of basic HFE issues, and incident reports that would be useful when preparing HFE training. An example HFE Screening tool is provided, as is a table of competence requirements for practitioners.

In summary, the OGP document reflects a relatively narrow HFE model when compared to some approaches (e.g. that of ASTM-F-1337, those based on the defence industry's Human Factors Integration and that of the UK's HSE). In this focused area the document provides practical guidance on resourcing, planning and carrying out an HFE programme on major capital projects. As an agreed approach for the industry it is a welcome addition to the HFE guidance in oil and gas.

\section{HFE success factors}

Several conditions for successfully integrating HFE onto projects are known; these factors are cru- 
cial because a human factors professional does not "own" anything in the system, and is powerless to impact the design unless these conditions (especially management and engineering buy-in) are present [5]. Some of the key recommendations are summarized below:

-Establish management commitment to HFE and appoint an HFE Champion (management commitment is essential; the HFE Champion promotes HFE issues and provides a link between the HFE practitioner and the project management team).

-Apply HFE during all phases of a project.

-Provide an early focus on known HFE problem areas and lessons learned from other facilities.

-Locate HFE personnel within the engineering design team to foster discussions and trust. It is more effective to act as an integrated part of the design team rather than an external enforcer of standards).

-Mandate HFE in the project design and mandate accepted HFE design standards in project specifications.

-Incorporate HFE activities into the programme plan.

-Provide management oversight of HFE activities.

-Require close cooperation between HFE, Operations / Maintenance and other engineering disciplines throughout the project lifecycle (ASTM-F-1337 and the OGP document recommend formation of a working group for large projects)

-Engage academically educated and experienced HFE professionals. HFE is a unique engineering discipline that applies specific knowledge of human capabilities and limitations and should not be assigned to other engineers from other disciplines, health professionals or former operators / maintenance staff.

As a relatively new discipline, it is important to effectively manage the integration of HFE on projects. Utilizing suitably qualified personnel to apply the appropriate tasks in a suitable organizational climate should maximize the success and impact of HFE on projects.

\section{Common HFE activities for Major Projects}

Table 1 summarizes the set of activities that are generally agreed-upon for a structured HFE programme for a Major Project. The reader is directed to the referenced guidance documents for further details on timing and competence required to plan and perform these activities.

Table 1

Summary of generally-agreed HFE Activities for Major Projects

\begin{tabular}{|c|c|c|c|}
\hline Activity Name & Project Phase(s) & Description & Tools Used / Method \\
\hline $\begin{array}{l}\text { Conduct HFE } \\
\text { Screening }\end{array}$ & $\begin{array}{l}\text { Concept Selection (identifying } \\
\text { basic trade-offs between op- } \\
\text { tions), and Selection (more } \\
\text { detailed screening when final } \\
\text { project concept is chosen) }\end{array}$ & $\begin{array}{l}\text { A structured and documented discussion to } \\
\text { establish the project's HFE requirements and } \\
\text { strategy. }\end{array}$ & $\begin{array}{l}\text { Screening tool (for an example, } \\
\text { see Appendix } 3 \text { of OGP guid- } \\
\text { ance document; [34]). }\end{array}$ \\
\hline $\begin{array}{l}\text { Write Project } \\
\text { HFE Strategy }\end{array}$ & Selection and Early Design & $\begin{array}{l}\text { A summary of Screening activity summarizing } \\
\text { key HFE risks and opportunities, activities and } \\
\text { applicable standards / references. Establish } \\
\text { HFE resource needs. }\end{array}$ & None (document). \\
\hline $\begin{array}{l}\text { Document, } \\
\text { Track and } \\
\text { Close-Out HFE } \\
\text { Issues }\end{array}$ & From Early Design to Operation & $\begin{array}{l}\text { A method for ensuring visibility, timely follow- } \\
\text { up and close-out of HFE issues. Should include } \\
\text { a formal method description for deviating from } \\
\text { HFE requirements. }\end{array}$ & $\begin{array}{l}\text { Spreadsheet, document or data- } \\
\text { base software } \\
\text { Human Factors Engineering } \\
\text { Working Group (for large } \\
\text { projects). }\end{array}$ \\
\hline $\begin{array}{l}\text { Review Project } \\
\text { Standards }\end{array}$ & Early Design & $\begin{array}{l}\text { Evaluating standards to ensure they support the } \\
\text { HFE strategy and planned activities. Ensuring } \\
\text { no conflicts between applicable standards and } \\
\text { local requirements. }\end{array}$ & None. \\
\hline $\begin{array}{l}\text { Conduct HFE } \\
\text { Awareness } \\
\text { training }\end{array}$ & Early and Detailed Design & $\begin{array}{l}\text { Educating management personnel, discipline } \\
\text { engineers, vendors and site inspectors on HFE } \\
\text { requirements, standards and expectations. }\end{array}$ & $\begin{array}{l}\text { Illustrations of HFE principles; } \\
\text { see Appendixes } 1 \text { and } 2 \text { of the } \\
\text { OGP guidance document [34] } \\
\text { for physical design and process } \\
\text { safety incident reports. Lessons } \\
\text { learned from comparable facili- } \\
\text { ties. }\end{array}$ \\
\hline
\end{tabular}




\begin{tabular}{|c|c|c|c|}
\hline Activity Name & Project Phase(s) & $\begin{array}{l}\text { Description } \\
\end{array}$ & Tools Used / Method \\
\hline $\begin{array}{l}\text { Generate HFE } \\
\text { Design Aids / } \\
\text { HFE Specifica- } \\
\text { tion }\end{array}$ & Early and Detailed Design & $\begin{array}{l}\text { Document establishing HFE goals and design } \\
\text { criteria for the project. }\end{array}$ & $\begin{array}{l}\text { Review of regulatory / company } \\
\text { / industry bodies' HFE guidance. }\end{array}$ \\
\hline $\begin{array}{l}\text { Develop Task } \\
\text { Analysis }\end{array}$ & Early and Detailed Design & $\begin{array}{l}\text { A list of activities associated with facility, area } \\
\text { or specific equipment items, broken down to } \\
\text { understand the constituent tasks. }\end{array}$ & $\begin{array}{l}\text { Specific software is available; } \\
\text { may also be performed using } \\
\text { spreadsheet / word processing } \\
\text { software. }\end{array}$ \\
\hline $\begin{array}{l}\text { Safety-Critical } \\
\text { task inventory }\end{array}$ & Early and Detailed Design & $\begin{array}{l}\text { Detailed breakdown of tasks that could lead to } \\
\text { serious consequences if performed incorrectly } \\
\text { or omitted. }\end{array}$ & As per Task Analysis. \\
\hline $\begin{array}{l}\text { Valve Criticali- } \\
\text { ty Analysis }\end{array}$ & Early and Detailed Design & $\begin{array}{l}\text { Classifying valves according to their criticality } \\
\text { within the process and frequency of use. }\end{array}$ & Project HFE criteria. \\
\hline $\begin{array}{l}\text { Control Room } \\
\text { Design Assess- } \\
\text { ment }\end{array}$ & Early and Detailed Design & $\begin{array}{l}\text { Evaluating design and layout of workstations } \\
\text { and the control room / suite. }\end{array}$ & $\begin{array}{l}\text { Various methods including Link } \\
\text { Analysis, General arrangement } \\
\text { drawing and 3D model reviews. }\end{array}$ \\
\hline $\begin{array}{l}\text { Facility Layout } \\
\text { Reviews }\end{array}$ & $\begin{array}{l}\text { Early and Detailed Design, and } \\
\text { Construction }\end{array}$ & $\begin{array}{l}\text { Evaluate layout for operability and maintaina- } \\
\text { bility. }\end{array}$ & $\begin{array}{l}\text { General arrangement drawings, } \\
\text { 3D model, Task Analysis, HFE } \\
\text { Design Aids checklist. }\end{array}$ \\
\hline $\begin{array}{l}\text { Vendor Package } \\
\text { Screening }\end{array}$ & $\begin{array}{l}\text { Detailed Design and Construc- } \\
\text { tion }\end{array}$ & $\begin{array}{l}\text { Assessing equipment (e.g. a pump package) } \\
\text { design against HFE standards. }\end{array}$ & $\begin{array}{l}\text { General arrangement drawings, } \\
\text { 3D model, Task Analysis, HFE } \\
\text { Design Aids checklist. Vendor } \\
\text { site visits during construction. }\end{array}$ \\
\hline $\begin{array}{l}\text { Review proce- } \\
\text { dures, manuals } \\
\text { and labelling } \\
\text { requirements }\end{array}$ & $\begin{array}{l}\text { Detailed Design and Construc- } \\
\text { tion }\end{array}$ & $\begin{array}{l}\text { Verify design and position of labels, signs and } \\
\text { markings. }\end{array}$ & $\begin{array}{l}\text { Physical inspection using HFE } \\
\text { Design Aids checklist. }\end{array}$ \\
\hline HCI Review & Early and Detailed Design & Evaluation of Human-Computer Interfaces & Various methods. \\
\hline $\begin{array}{l}\text { Review Alarm } \\
\text { System }\end{array}$ & Detailed Design & $\begin{array}{l}\text { Review each alarm signal to ensure it signifies a } \\
\text { meaningful operator action and the system } \\
\text { avoids alarm overload, alarm "chattering" etc. }\end{array}$ & $\begin{array}{l}\text { Alarm Objectives Analysis / } \\
\text { Alarm Rationalization }\end{array}$ \\
\hline $\begin{array}{l}\text { Review Ac- } \\
\text { commodation } \\
\text { Design }\end{array}$ & Early and Detailed Design & $\begin{array}{l}\text { Verify suitable space provision, layout, emer- } \\
\text { gency egress etc. within accommodation areas. }\end{array}$ & $\begin{array}{l}\text { Various, including HFE Design } \\
\text { Aids checklist. }\end{array}$ \\
\hline $\begin{array}{l}\text { Assist Material } \\
\text { Handling }\end{array}$ & Early and Detailed Design & $\begin{array}{l}\text { Ensure suitable provision of lifting aids to assist } \\
\text { / reduce manual handling. }\end{array}$ & $\begin{array}{l}\text { General arrangement drawings, } \\
\text { 3D model, Task Analysis, HFE } \\
\text { Design Aids checklist. }\end{array}$ \\
\hline $\begin{array}{l}\text { Evaluate Noise } \\
\text { and Vibration }\end{array}$ & Early and Detailed Design & $\begin{array}{l}\text { Identify high-noise items, evaluate means of } \\
\text { reducing noise exposure (activity is usually } \\
\text { performed by a Noise \& Vibration specialist). }\end{array}$ & $\begin{array}{l}\text { Various specialist software } \\
\text { packages. }\end{array}$ \\
\hline $\begin{array}{l}\text { Evaluate Crane } \\
\text { Operations }\end{array}$ & Early and Detailed Design & $\begin{array}{l}\text { Identify layout for lifting needs and evaluate } \\
\text { crane control cabin design, layout and interface. }\end{array}$ & $\begin{array}{l}\text { General arrangement drawings, } \\
\text { 3D model, Task Analysis, HFE } \\
\text { Design Aids checklist. } \\
\text { Crisis and Operability (CRIOP) } \\
\text { Study [35]. }\end{array}$ \\
\hline $\begin{array}{l}\text { HFE in Con- } \\
\text { struction }\end{array}$ & Construction & $\begin{array}{l}\text { Guide the construction contractor with respect } \\
\text { to installing equipment not normally shown in } \\
\text { 3D CAD models (e.g. small-bore piping and } \\
\text { tubing, cable trays etc.) }\end{array}$ & $\begin{array}{l}\text { HF awareness training } \\
\text { On-site inspections. }\end{array}$ \\
\hline $\begin{array}{l}\text { Conduct follow- } \\
\text { up evaluation }\end{array}$ & $\begin{array}{l}\text { Operation (1-year post-startup } \\
\text { is suggested) }\end{array}$ & $\begin{array}{l}\text { Review: } \\
\text { The level of operability and maintainability } \\
\text { achieved } \\
\text { HFE issues identified during operations } \\
\text { Incidents and near-misses } \\
\text { Lessons to be fed back } \\
\text { Identification of HFE value. }\end{array}$ & $\begin{array}{l}\text { Structured meeting with opera- } \\
\text { tions personnel. }\end{array}$ \\
\hline
\end{tabular}




\section{Conclusions}

There is now specific HFE guidance written for the oil and gas industry; the available documents are fairly consistent, describe an agreed approach and set out to explain how to plan and carry out HFE activities for major offshore projects. They also provide specific HFE based design criteria which is mandatory for a successful HFE program. This situation has evolved over a period of over 20 years during which established guidance from other industries has been tailored to the needs of the oil and gas industry.

$20+$ years of experience has clearly shown the value of adding HFE to the design of ships and offshore structures. Further, it has been repeatedly demonstrated that this can be done in a cost effective way.

A partial list of projects that have applied HFE is shown in Table 2. This gives an indication of the range of world regions and scales of projects to which HFE has been applied.

The application of HFE remains inconsistent and some barriers to implementation still exist. However there is evidence of increasing regulatory interest in the importance of HFE, driven by incidents and increasing recognition of the need to support human performance. Now with guidance established for the oil and gas industry the HFE discipline may make further progress towards consistent application on oil and gas projects.

Table 2

Partial list of oil and gas projects that have applied HFE

\begin{tabular}{|c|c|c|c|c|}
\hline Facility Name & Description & Year(s) & Location & HFE Activities \\
\hline Auger & Tension Leg Platform (TLP) & $\begin{array}{l}1990 \\
2001\end{array}$ & Gulf of Mexico & $\begin{array}{l}\text { HFE Programme during design and } \\
\text { construction; } \\
\text { Review and upgrade of new control } \\
\text { room. }\end{array}$ \\
\hline Boxer & Shallow Water Fixed Platform & 1990 & Gulf of Mexico & $\begin{array}{l}\text { HFE audit of small existing plat- } \\
\text { form. }\end{array}$ \\
\hline Harvest & $\begin{array}{l}\text { Shallow Water Fixed Drilling } \\
\text { Rig }\end{array}$ & 1991 & Gulf of Santa Barbara & $\begin{array}{l}\text { HFE review of Ship Traffic Con- } \\
\text { trol System. }\end{array}$ \\
\hline Main Pass 289-C & Shallow Water Fixed Platform & 1991 & Gulf of Mexico & $\begin{array}{l}\text { HFE evaluation of aux Control } \\
\text { Room and Building Design. }\end{array}$ \\
\hline Main Pass 252-A & Shallow Water Fixed Platform & 1991 & Gulf of Mexico & $\begin{array}{l}\text { HFE evaluation of Production } \\
\text { Module and Building Design. }\end{array}$ \\
\hline Monarch & Jack-up Drilling Rig & 1991 & South China Sea & $\begin{array}{l}\text { HFE audit of total rig design for } \\
\text { new built rig }\end{array}$ \\
\hline Mars and Mars B & TLP & 1993 and 2009 & Gulf of Mexico & $\begin{array}{l}\text { HFE Programme during design and } \\
\text { construction. }\end{array}$ \\
\hline Amy Chouest & Offshore Supply Vessel & 1993 & Gulf of Mexico & HFE evaluation of Bridge. \\
\hline Mars Turbine & Offshore Gas Turbine Enclosure & 1993 & San Diego, CA & $\begin{array}{l}\text { HFE review of turbine design and } \\
\text { total turbine package layout in its } \\
\text { enclosure }\end{array}$ \\
\hline $\begin{array}{l}\text { Schat Watercraft } \\
\& \text { Survival Sys- } \\
\text { tems }\end{array}$ & Offshore Lifeboats & 1994 & $\begin{array}{l}\text { Valley Center, CA. \& } \\
\text { New Iberia, LA }\end{array}$ & $\begin{array}{l}\text { HFE evaluation for ease of opera- } \\
\text { tion and maintenance }\end{array}$ \\
\hline Main Pass 143 & $\begin{array}{l}\text { Shallow water Fixed oil and gas } \\
\text { transfer platform }\end{array}$ & 1994 & Gulf of Mexico & $\begin{array}{l}\text { HFE design inputs to conversion of } \\
\text { an existing platform }\end{array}$ \\
\hline Ram-Powell & TLP & 1996 & Gulf of Mexico & $\begin{array}{l}\text { HFE Programme during design and } \\
\text { construction. }\end{array}$ \\
\hline Sable Offshore & Three Offshore Gas Platforms & 1996 & $\begin{array}{l}\text { Off coast of Nova } \\
\text { Scotia, Canada }\end{array}$ & $\begin{array}{l}\text { Total HFE effort for platform de- } \\
\text { signs }\end{array}$ \\
\hline Ursa & TLP & $\begin{array}{l}1998 \\
2001\end{array}$ & Gulf of Mexico & $\begin{array}{l}\text { Initiated HFE for Ursa Project; } \\
\text { Review and upgrade of new control } \\
\text { room. }\end{array}$ \\
\hline $\begin{array}{l}\text { Ocean Confi- } \\
\text { dence }\end{array}$ & Deepwater Drilling Rig & 1998 & Worldwide & $\begin{array}{l}\text { HFE for conversion of hotel plat- } \\
\text { form to drilling rig }\end{array}$ \\
\hline Terra-Nova & $\begin{array}{l}\text { Floating Production, Storage } \\
\text { and Offloading facility }\end{array}$ & 1999 & $\begin{array}{l}\text { North Atlantic off } \\
\text { Newfoundland, Cana- } \\
\text { da }\end{array}$ & $\begin{array}{l}\text { HFE design and layout of the Tur- } \\
\text { ret Disconnect Panel }\end{array}$ \\
\hline
\end{tabular}




\begin{tabular}{|l|l|l|l|l||}
\hline \multicolumn{1}{|c|}{ Facility Name } & \multicolumn{1}{|c|}{ Description } & \multicolumn{1}{c|}{ Lear(s) } & \multicolumn{1}{c||}{ HFE Activities } \\
\hline $\begin{array}{l}\text { Discoverer En- } \\
\text { terprise }\end{array}$ & Deepwater Drill Ship & 2000 & Gulf of Mexico & $\begin{array}{l}\text { HFE team evaluated total drilling } \\
\text { process and equipment }\end{array}$ \\
\hline Agbami & FPSO & 2000 & Nigeria & $\begin{array}{l}\text { Review of all design project docu- } \\
\text { ments for HFE requirements }\end{array}$ \\
\hline Na-Kika & TLP & 2001 & Gulf of Mexico & $\begin{array}{l}\text { HFE design input and concept } \\
\text { layouts for the control room }\end{array}$ \\
\hline Agbami & FPSO & $2001-2007$ & Nigeria & $\begin{array}{l}\text { HFE Program from FEED through } \\
\text { Construction \& HUC project phas- } \\
\text { es }\end{array}$ \\
\hline Benguela-Belize & Compliant Tower & 2003 & Angola & HFE design input to CCR design \\
\hline Tahiti & Spar & 2004 & Gulf of Mexico & HFE Framing Workshop \\
\hline $\begin{array}{l}\text { Boabab Field } \\
\text { Development }\end{array}$ & FPSO & 2004 & Ivory Coast & $\begin{array}{l}\text { HFE support in design of CCR via } \\
\text { CAD concept layouts) }\end{array}$ \\
\hline Frade & FPSO & 2006 & Campos Basin, Brazil & $\begin{array}{l}\text { Total HFE support including con- } \\
\text { trol room layout }\end{array}$ \\
\hline Valhall & Shallow Water Fixed Platform & 2007 & $\begin{array}{l}\text { North Sea (Norwegian } \\
\text { Sector) }\end{array}$ & $\begin{array}{l}\text { Structured Working Environment } \\
\text { programme during design and } \\
\text { construction }\end{array}$ \\
\hline Goliat & FPSO & 2010 & $\begin{array}{l}\text { North Sea (Norwegian } \\
\text { Sector) }\end{array}$ & $\begin{array}{l}\text { Structured Working Environment } \\
\text { Programme }\end{array}$ \\
\hline Cheviot & Semi-Submersible & 2011 & North Sea (UK Sector) & HFE support to Topsides design \\
\hline
\end{tabular}

\section{References}

[1] Brazil Energy Data, Statistics and Analysis - Oil, Gas, Electricity, Coal. U.S. Energy Information Administration, January 2011. Available at:

http://www.eia.gov/cabs/brazil/Full.html.

[2] Petrobras Says Brazil Oil Reserves Similar Size to North Sea. Reported in Bloomberg Businessweek, July 14, 2011. Available at: http://www.businessweek.com/news/2011-0714/petrobras-says-brazil-oil-reserves-similar-size-to-northsea.html.

[3] Petrobras to launch tender for 28 oil rigs in Sept. Reuters, Fri Sep 11, 2009. Available at:

http://www.reuters.com/article/2009/09/11/brazil-oil-rigsidUSN1145832520090911.

[4] Brazil, the New Oil Superpower. Reported in Bloomberg Businessweek, November 19, 2007. Available at: http://www.businessweek.com/bwdaily/dnflash/content/nov20 07/db20071115_045316.htm.

[5] A Brief History of the Utilization of Human and Organizational Factors (HOF) in the Design of Military and Commercial Ships and Offshore structures in the United States. Gerald E. Miller and Kevin Mcsweeney. In International Conference on Human Factors in Ship Design and Operation (2000).

[6] Human Factors Engineering (HFE) and Cultural Calibration for Vessel and Offshore Installation Design. Chapter 4 in "Advances in Human Performance and Cognitive Engineering Research", Volume 4. Elsevier, 2004.

[7] Further developments of standards, specifications, and guidelines related to human and organizational factors (HOF) to reduce human error in offshore facilities and operations, 1998. Rajiv Khandpur, Compliance Division (G-MOC-2), United States Coast Guard, Washington D.C.

[8] Miller G.E., Bockosh G., Edmondson N., Holdsworth R., Khandpur R., Mello J., \& Mirabella J. (1997) Further Developments of Standards, Specifications, and Guidelines Related to Human and Organizational Factors (HOF) to Reduce Human Error in Offshore Facilities Operations. In R.G. Bea, R.D. Holdsworth, and C. Smith (Eds.), 1996 International Work- shop on Human Factors in Offshore Operations. New York: American Bureau of Shipping.

[9] Recommended Practice for Development of a Safety and Environmental Management Program for Offshore Operations and Facilities. API Recommended Practice 75, Third Edition, May 2004. American Petroleum Institute.

[10] Regulators' use of standards. Report No. 427, March 2010. International Association of Oil and Gas Producers. Available at: http://www.ogp.org.uk/.

[11] Assessment Principles for Offshore Safety Cases (APOSC). Health and Safety Executive. Available at: http://www.hse.gov.uk/offshore/aposc190306.pdf.

[12] Health and Safety Executive. Human Factors and Ergonomics. Available at: http://www.hse.gov.uk/humanfactors/.

[13] Human Factors: Design. HSE. Available at: http://www.hse.gov.uk/humanfactors/topics/design.htm.

[14] Human Factors Integration: Implementation in the onshore and offshore industries (2002). Available at: http://www.hse.gov.uk/research/rrpdf/rr001.pdf.

[15] Challenge and Change: doing business differently. A presentation made at the International Offshore Petroleum Regulators \& Operators Summit, 11 August 2011. Available at: http://www.nopsa.gov.au/presentation/Presentation $\% 20$ $\% 20 I O P R O \% 20$ Summit $\% 20$ $\% 2011 \% 20$ August $\% 202011$.pdf.

[16]Personal communication from NOPSA, July 2011.

[17]NORSOK S-005 Machinery -Working Environment Analyses and Documentation (1999). Standards Norway. Available at: http://www.standard.no/PageFiles/1048/S-005.pdf.

[18] NORSOK S-002 Working Environment (2004). Standards Norway. Available at: http://www.standard.no/PageFiles/1050/S-002.pdf.

[19] The present scenario in Brazilian Oil and Gas Sector. Magda Chambriard, Director, Brazilian Petroleum Agency. Keynote presentation given by Claudia Rabello. Brazil Energy \& Power VIII, August 23, 2010.

[20]'Crown Jewel' Rig Will Go Ultra-Deep for New Oil. CNBC, Tuesday, 26 Apr 2011. Available at: http://www.cnbc.com/id/42683782/Crown_Jewel_Rig_Will_G o_Ultra_Deep_for_New_Oil. 
[21] IEEE Guide for the Application of Human Factors Engineering to Systems, Equipment, and Facilities of Nuclear Power Generating Stations (1023-1988). ISBN 0-7381-0724-7. Available at:

http://ieeexplore.ieee.org/xpl/freeabs_all.jsp?arnumber=29133.

[22] IEEE Guide for the Application of Human Factors Engineering in the Design of Computer-Based Monitoring and Control Displays for Nuclear Power Generating Stations (1289-1998).

[23] IMO Circular 834: Guidelines for Engine-Room Layout, Design and Arrangement (1998). International Maritime Organization.

[24] IMO Circular 982: Guidelines on Ergonomic Criteria for Bridge Equipment and Layout (2000). International Maritime Organization.

[25] American Society of Testing and Materials (ASTM) International. ASTM F1337 - 10. Standard Practice for Human Engineering Program Requirements for Ships and Marine Systems, Equipment, and Facilities, 1991.

[26] American Society of Testing and Materials (ASTM) International. F1166 - 07. Standard Practice for Human Engineering Design for Marine Systems, Equipment, and Facilities, 2000.

[27] Human Engineering. Department of Defense Design Criteria Standard. Mil-Std 1472, 1989.

[28]Human Factors Engineering (HFE) and Cultural Calibration for Vessel and Offshore Installation Design, Denise B. McCafferty, E.Johan Hendrikse, Gerry E. Miller. in Michael Kaplan (ed.) Cultural Ergonomics (Advances in Human Performance and Cognitive Engineering Research, Volume 4), Emerald Group Publishing Limited, pp.105-145.
[29] American Bureau of Shipping (ABS) Guide For Crew Habitability on Offshore Installations. ABS, 2002 (available at: http://www.eagle.org/eagleExternalPortalWEB/ShowProperty/ BEA\%20Repository/Rules\%26Guides/Current/105_CrewHabi tabilityOffshoreInstallations/Pub105_CrewHabitability_Offshore).

[30]American Bureau of Shipping (ABS) Guidance Notes on the Application of Ergonomics to Marine Systems (2003). Available at:

http://www.eagle.org/eagleExternalPortalWEB/ShowProperty/ BEA\%20Repository/Rules\%26Guides/Current/86_Applicatio nsofErgonomicstoMarineSystems/Pub86_ErgoMarineSystems.

[31] Integration of Human Factors Engineering into Design -An Applied Approach. K.P. McSweeney, J. Pray and B.N. Craig. ABS Technical Papers, 2009.

[32] American Bureau of Shipping (ABS) Guidance Notes on the Implementation of Human Factors Engineering into the Design of Offshore Installations. Not yet published; Expected 4th Quarter 2011.

[33] Safety in Designs Incorporating Human Factors (SID-SU5106-A). Chevron Corporation, 2008).

[34]Human Factors Engineering in Projects. Report No. 454, August 2011. International Association of Oil and Gas Producers. Available at: http://www.ogp.org.uk/pubs/454.pdf.

[35]CRIOP: A scenario method for Crisis Intervention and Operability Analysis. SINTEF Industrial Management, Safety and Reliability. Available at: http://www.sintef.no/ 